\title{
Philosophical concept of the state power (social power) and the military (the armed force)
}

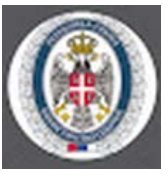

Received: 26/09/2021

Revised: 02/10/2021

Accepted: 05/10/2021

Published: 06/12/2021

Corresponding author: Ilija Kajtez

Correspondence email: ilijasbm@ptt.com

DOI:

10.5937/vojdelo2103009K

\begin{tabular}{|l|l|l|l|}
\hline c & e & o & n \\
\hline c & e & e & s \\
\hline
\end{tabular}

\author{
Ilija Kajtez \\ Univerzitet "Union - Nikola Tesla", Fakultet za međunarodnu politiku i bezbednost, \\ Beograd
}

\begin{abstract}
:
In the paper the author would like to explain why the concept of the social power is relevant for the state power, and why it is more appropriate for the military to talk about the armed force. Although he is acutely aware of the intertwining, reciprocity and closeness of the state power and the organization of the military, as well as the concepts of power and force, the author would like to emphasize their differences. It is not possible to talk about the power without the help and reliance on the armed force, and there is no armed force that does not view its meaning, task and goal in the state power. The military power can be independent only in short periods, but it immediately returns to the state power or the very military establishes the state power because it needs a source of legitimacy. What is the first and main rule is that we cannot talk anywhere about true power unless the one in power controls the armed force in his community, tribe, family, class, politics, state and society. It is simply impossible to imagine, let alone really happen, that the one who rules a community or society is not the supreme commander of the armed forces, as well. The main idea is to consider what are the inviolable spheres of the society in which politics should dominate, and where the best field of action of the armed forces is and how and in what way their relations, which are close, but often tense, are regulated.
\end{abstract}

Keywords: power; state power; military; armed force; loyalty; civil-military relations

\section{THE CONCEPTUAL DEFINITION OF THE SOCIAL POWER AND ARMED FORCE}

Defining the concepts of force and power is not at all easy and simple, after all, as when it comes to all social concepts. An important problem in defining the concepts of force (the armed force) and power (the social power) is that these concepts are intertwined, have almost the same meaning and are closely related to each other, and some authors often use them as synonyms [1]. However, for the sake of precision, scientificity and objectivity, their differences and specifics should be described and emphasized. One of the most important social phenomena studied by the sociology of politics (and other social sciences) is power. Power [2] is a magic word that fascinates and amazes the political world today. This is the most important paradigm of the postmodern, neoliberal, spiritless and consumerist world. Being (super)powerful over enemies is the dream of all rulers, tyrants, military leaders and military-political alliances. Power becomes authority when it is well organized and institutionalized (strengthened, accepted and prolonged). The most important organization of the public authority in the modern age (society) is the state.

What is force? It seems we all know what it is about, but is it true? First of all, in social textbooks, dictionaries and chrestomathies, there are not many definitions of the concept of force. The philosophical concept of force says: "Force (Greek dynamis; Latin vis), in the broadest sense, the ability to act. Since it is hidden behind every action, it often means the cause of an action. The genesis of the concept of force is interpreted by some... that the direct experience... of the action of one's own body... as well as the experience of voluntary effort... have led to the creation of the concept of force projected in events in... areas: material, life and spiritual. By suppressing personified concepts of force in... the mythologies of philosophical-scientific research on the essence of force in Greece, he first defined the principle that every movement and change has a cause and confirmed that 'force is the 
cause of movement and change' (Aristotle)... modern natural science views force as a quantitative relation... And... many philosophers of the modern age, trying... to determine the essence of force vary the Aristotelian idea... or resort to a more anthropomorphic interpretation of force (visactiva Leibniz, willing and active MainedeBiran 'will and performance' Schoppenhauer, 'life zeal' Bergson)" [3]. Force has several meanings, and it mainly refers to natural phenomena, which for us in social sciences is not something that is relevant because we are interested in force as a social phenomenon. Force indicates some energy released by physical or social movements, as well as the ability to act actively in space or social relations. In social sciences, force is the ability to act and coerce. We associate the concept of force with the armed force.

A close concept to force is violence [1], which means: "the acting by force to create a certain situation or relationship in the society, which leads to the achievement of goals and interests of the perpetrator, and contrary to the will and interests of those participants in the interaction against whom violence is committed" [4]. The following relationship between force and violence is also interesting [1]. The characteristic of force is: "... in essence, although... necessary, at the same time, always an extreme and unpopular means of exercising power due to the brutality of the apparent effects of its concrete, i.e. direct, implementation as obviously inhumane activity. Brute force should be the last means of exercising power... In case of the need of its use, it is necessary to use it as little as possible and rationally... because...any irrational, excessive, ... and insufficient, use of force...intensifies resistance and revolt more than it secures obedience or builds authority. The degree...of the ability to use force can be defined as the degree of possibility of its rapid, timely and by actors...means, scope and intensity-goal and conditions, appropriate use" [1]. If force is related to the concept of the armed force (the military), the previous explanation well and faithfully describes the situation when and in which socially justified way the military can be used and the best military (the armed force) is the one that is the factor of peace and deterrence of the enemy, and also the most effective power (the social power) is the one that is not actively (violently) demonstrated in the street (squares), but is accepted almost without discussion and great resistance from its residents. The Chinese military leader Sun Tzu wrote in his book The Art of War: "The greatest skill of a warrior is to win and conquer the enemy without fight, which is possible only by conquering the enemy spirit" [5]. Thus, the use of the armed force is by its very act an initial defeat. However, if it is necessary to use it then the demonstration of the armed force has to be rational, short-lived and with as few casualties as possible because each blood shed increases resistance to the (military) force and armed violence and makes the armed force and every force less likely for clean and quick victory [6]. The main goal of the use of each armed force is to turn the military victory into the legitimate power-the authority. The use of the armed force is not an end in itself, but its main goal is to end the demonstration of force as soon as possible with peace that becomes power. Of course, in favour of the military winner. Niccolo Machiavelli thinks that there are two ways to fight in the country: by law and by force, whereby he connects authority (power) and force.

What are the other relations of the social power and force (the armed force)? "If force as an instrument of coercion is a means of establishing and expressing power, then...power means the authority expressed through the requirement for obligatory as legitimate expression" [1]. Force is a means of exercising and maintaining power, and violence is a way of expressing and exercising power. Still, power is not fulfilled only by force, and violence is not an obligatory way of fulfilling power. However, it is wrong to interpret that "force does not have to be in correlation with power" [7] because where there is force there is also power, and every act of social (political) violence is connected with the expression of political power. Force is not the only basis of power, but power always means the possibility of controlling the means and ways of using force. It was noticed in the ancient Greece that power and force are closely connected, but not the same. "In Aeschylus tragedy 'Prometheus Bound', the Power and Force appear as Zeus' servants who lead Prometheus in chains, and then supervise Hephaestus, whose task is to bind Prometheus forever with his divine blacksmith's tools and unbreakable shackles. The Power...commands, warns and threatens. Hephaestus, reluctantly executing his task, shouts to it: 'You, always cruel and full of insolence!' And when he tells it that he knows what he has to do and that it does not command him more, the Power answers: 'I will command and shout 
louder' and 'You can be soft, but do not use my inflexibility/and fierceness of my heart.' [8] All the time, the Force is present on the stage without words, but the fact that it does not say the verses does not mean that its appearance is not necessary. Without the Force, the Power would also be silent" [9]. By the way, only Apollo, the God of Arts, and Athena, the Goddess of Wisdom, dared to contradict Zeus, the ruler among the Gods [10].

We will mention only the main characteristics of power (the social power). Power is an (ancient) old social phenomenon, and one of the basic constants in interpersonal and social relations. Barle claims that power and love are the two oldest phenomena of human emotion [11]. Man has a twofold relationship to power: power is embedded in the highest reach of civilization, but it is thought to be responsible for human suffering and great injustice. Power can be personal, group, state and social. Machiavelli, who was the first theorist of power in modern times, points to two important features of power. Thomas Hobbes was the first modern philosopher of power. Max Weber defines power as the use of: "every chance to carry out one's own will within a social relationship, even against resistance and regardless of what that chance is based on." Mishael Foucault views power as ubiquitous and dispersed [12]. He believes that there is no institution that expands its power. Power does not belong to a social group; it is everywhere, in everyone. ${ }^{2}$ In the society it represents the relation between human subjects. Power can be viewed as the ability to regulate and predict the behaviour of others, while being unpredictable ourselves [13]. Bertrand Russell believes that power in social sciences has the same status as energy in physics. According to Russell, there are two main desires among people: the desire for power and the desire for fame. Although not identical, they are closely related. Oppenheimer defines power as the ability to influence, limit or punish [14]. Gajo Petrović claims that "power as supremacy in the germ contains violence" [15] because the perpetration of violence is a manifestation of power. There are authors who believe that violence can be a manifestation of powerlessness, as well, after all, as it can be a sign of decline or disappearance of authority, and in other cases power can act openly and brutally, and its influence be small [16]. "Force acts even when it is not used directly, which can be seen from a number of historical examples in which force has influenced the fulfillment of certain interests of the one who possesses it by its very existence. Such action of force can grow to the limits of violence, but only as indirect violence by which the opposite sex is direct violence..." [1] Power is a very complex concept and hides many secrets, so it is necessary to speak carefully and categorically claim power. "We need a broader concept than the concept of violence and broader than the concept of peace. Such a concept is power. Cultural power moves actors, imposing on them the attitudes about what is good, and what is bad; economic power drives them by the carrot method... the military power (or 'force' in general) by the stick method, meaning by the 'opposite' method; political power drives them by the decision-making. Thus, we distinguish four kinds of power, or four discourses: cultural, economic, military and political" [17].

It is necessary to look for differences and specifics of the concepts of force and power, although it is not at all simple and can lead to simplification, artificial and constructed and imposed distinctions, which should certainly be avoided at all costs. Dragan Simeunović points out: "understood simply as strength, energy, and even as 'energy of power' [18], social power is always insufficiently distinguished from power, i.e. energy as a physical phenomenon if its productive and teleological social dimension in terms of human and society self-realization is not emphasized." Based on the mentioned facts and claims, we can conclude that the concept of the social power is broader, more complex and more comprehensive than the concept of force (the armed force), which is a derived category compared to the social power, that the social power is connected to economic basis (production) that force (the armed force) is not in the most direct connection, but it is indirect. ${ }^{3}$ It is particularly important that power contains the teleological dimension of the society, which belongs to the domain, above all, political action, and in the execution of teleological action of the political community of forces (the armed force) is only an (important) instrument for carrying out political goals. ${ }^{4}$ The foundations of the social power are not only material, but also social and psychological in nature, while the military power does not have that breadth and comprehensiveness. 


\section{THE MILITARY AND POLITICS}

Rarely has some profession like the military one, except perhaps the political profession, been so firmly, permanently and multiple connected with the state apparatus and state policy [2]. The military factor has had a great influence on all events in history over the centuries. ${ }^{5}$ The specifics of the military profession, in addition to its influence in history, is the relative separation of the military from other parts of the society. ${ }^{6}$ In modern society, the military is connected to the whole of the society, especially through the state power [19]. And it will always be like that. The ruler or the person who is the supreme authority in the state is also the supreme commander of the Armed Forces. In his book The Prince Machiavelli writes: "The main foundations of all governments, both new and old or mixed, are good laws and the military." When it comes to the military, as a pillar of the state power, its warning that all armed prophets have won, and unarmed ones have failed, is important. In the ancient times and the modern world, there are different practices of the relation between the state and the military, which depends on the tradition of people, its political culture and political system, but one thing is common to all states and their political systems, and that is lasting, interest-based connection and mutuality of the military and politics (power) of a country. That connection is close and unbreakable. It is therefore necessary for each officer to know the phenomenon of politics, the political system of their country and the functioning of the state (public) and local government. It is important to know the place, role, importance of the military, as the rights and duties of the military in the state system and the attitude of its members towards the public policy. Due to the importance of the military and the possession of the monopoly of physical force, the power has to precisely define the place and role of the armed forces in the political system of the state.

When it comes to the relation between politics and the military, we encounter a paradox in politics that was discussed in the ancient Greece, and that is: "... usually unarmed civilians are those who receive and seek obedience from those who manage weapons and who are therefore physically capable of imposing their will on civilians" [4]. As it seems, these are some of the important issues of political theory and political science. The main cause of the (dis)obedience of the military is not physical, but psychological. "In terms of the physical balance of power... the military can easily defeat unarmed civilians... However, the military usually has the power to rule, but does not always have the will. It also does not always operate in conditions conducive to the takeover of political power... The political culture of a nation determines both the attitudes of the military and the attitudes of people towards the military. It... explains why some... political systems are strong and effective, while others are weak, unsuccessful or prone to revolt" [4]. According to some authors [20] civil-military relations are carried out in the relations between the military, political elites and civil society. ${ }^{7}$ High-ranking officers actively participate in the development of the military policy, political elites have the greatest influence on the size, composition and missions of the military, and the civilian sector indirectly influences politics and the military through elections, public opinion and mass media. The purpose of these relations is to better integrate the military into economic, cultural and political life of the society. It is important that it is professional and competent, equipped with modern weapons and equipment, but it is crucial that it is loyal to its people, state and democratically elected government. It is also important that the soldier uses weapons well, but the most important thing is who these weapons-equipment is aimed at. That is the greatest concern and task of the state power.

At the end of the 18th century, during the Bourgeois revolutions, the political issues of the role, place and control of the military in the democratic society came to light because the occurrence of the people's armies (general recruitment) significantly changed the relation between the military and power. Some philosophers believe that the military is a danger to the freedom of the community [19], such as Edmund Burke: "The army is a disciplined body, and as such... is dangerous to freedom; if it is undisciplined then it is a disaster for the society." ${ }^{9}$ This issue was addressed by statesmen and thinkers in the United States after the victorious revolution for independence (1775-1883). The opinions on whether the United States need a standing army were divided. 
Every state power needs to concentrate all powers in its hands, and one of the strongest levers of government is the monopoly of physical force at the disposal of the military, and that is why every power wants to control the military first. ${ }^{11}$ Power determines the rules of the social game. The very complex relation between politics, power and the military has changed throughout history, which is not surprising, having in mind various interests, political culture and the organization of power.

In the world today, the military is mainly subordinated to democratically elected political power. However, it happens that the military imposes itself on the entire society and then it manages and commands the society that it should serve, above all. Such a model, according to which the military imposes its will on the society, is implemented by the military regimes in less developed countries. ${ }^{12}$ In Latin America, after gaining independence (19th century), the military regimes emerged, and this model appeared in the postcolonial African countries, and, to a lesser extent, Asia. The main reason for taking over the military power is the inefficiency of politics and the lack of legitimacy of civilian regimes. In the 20th century, the military regimes were oriented towards the poor. They were, ${ }^{13}$ in some cases, able to produce economic development and modernization, but they mainly suffered complete failure.

It is important to understand the need for cooperation between politics and civilians with the military and command staff because this is imposed by important contemporary tendencies in the development of the military and the understanding of politics. It mainly means the rapid technical and technological development of the military, which a politician cannot easily master and which (the military) plays a very important role in defining the foreign policy of each country. The army has a significant in its hands. A significant part of the national income is directed to the military, and it influences the decisions of the government. The military is competent to perform numerous security and political tasks in the world, especially when it comes to peacekeeping and humanitarian missions. The civil and democratic control over the military is important because: "The military is... a hierarchically organized social organization in which an individual who commands in the war has great... absolute powers because... he decides on the lives... of subordinates. That fact alone is enough to impose the need for a broader social insight and influence on the operation and use of such an organization" [19].

\section{PROPOSAL FOR THE IMPROVEMENT OF THE CIVIL AND DEMOCRATIC CONTROL OVER THE SERBIAN ARMED FORCES}

The relation between the military and politics will always be of special interest to every state power. It is important, but also changeable, although the civil control over the military has reached a high level, especially in democratic countries, and confirmation that the military will not take over those competencies that do not belong to it in the political field. However, social phenomena are very dynamic and the entire society has to watch over the values of democracy. In modern and developed democracies, no one has absolute power, and power is not concentrated in a person or organization, but is scattered in many different institutions, some of them are state ones, others belong to the civil society, so the political decision-making process is complex. The democratic state is a polyarchy, the rule of many [21]. If they act in agreement and unity, the military power significantly increases the political (social) power and contributes to its reputation. The loyalty of the Serbian Armed Forces personnel to the democratically elected civil authorities of the Republic of Serbia has never been and should never be questioned. The Serbian soldiers belong to their state and their people. They know well that the people are the only sovereign, and that the state power is formed on the basis of the majority will. Respecting their people, the Serbian Armed Forces members, who are superior in the military sense, are loyal to the state authorities.

The attitude of soldiers towards power is very simple.

According to positive laws, they welcome in their environment, with all the prescribed honours, the one who has won power, but they also treat the opposition with due respect and attention because it 
is also a part of the political system of our country. However, neither the government nor the opposition can propagate party views in the premises of the Serbian Armed Forces. The professional soldiers of the Serbian Armed Forces cannot be party organized, they cannot represent and spread party ideologies and values at work or in public, they cannot be members of parties, nor in their lists. According to the law, the Serbian Armed Forces members have the active voting right - to vote for the person who, in their opinion, will best represent the state. On the contrary, it is very easy for the state power to relate to the Serbian Armed Forces and it should replace (if it would like) a few leading people at the most when it comes to power, and professional soldiers should continue with their regular work. If a member of the Serbian Armed Forces is not satisfied with the government or the policy that the state pursues towards the Armed Forces, there are only two alternatives: to agree with such a policy or to terminate his professional service.

However, the loyalty of the Armed Forces does not mean that their voice is not heard and respected in the professional, personnel, technical and technological sense. Still, there are some important internal issues, where the model of the relation between the civil and military power should have a semi-directed relationship. Namely, some authorities in Serbia have behaved in a voluntaristic manner and have not consulted with the military profession, contributing in such a way, to the weakness, inefficiency, demotivation and weakening of the Serbian Armed Forces. Namely, if the civil power, without any consultations with the military top brass, puts in a leading position in the Armed Forces an officer without sufficient military knowledge and who has commanded only a platoon in his professional career and comes from the logistic basis of the Armed Forces, and not from the "firing pin" (pilots, air defence officers, infantry, artillery, armoured vehicles, paratroopers) then great problems arise in chain of command, which causes justified revolt of all officers who aspire to the leading position with their knowledge, career and capabilities. The voluntarism of the civil authorities, unjustified in any way, and at least for professional, patriotic and state reasons, is fatal and unacceptable.

I propose a model that would solve many problems in the communication between the civil and democratic authorities and the Serbian Armed Forces members, not questioning the loyalty of soldiers to their democratic government, whose essence lies in the career development of officers. Namely, after completing studies, the top ten are singled out, and their characteristics are recorded in a special file. After four or five years, out of those ten officers, 2-3 lowest ranked are eliminated in order to be replaced by those who have proved to be the best in the meantime. In five years the procedure is repeated. Thus, according to the same model, officers would advance throughout their careers. So, the government could then send to school or appoint to the most responsible positions only the best ones. This is a possible model of a semi-directed relation between the state power and the military. In that way, the situation that those who do not deserve it and do not meet the conditions are promoted or sent to a career school would be avoided. The voluntaristic approach of the civil authorities destroys the order and capability of the Serbian Armed Forces, in which the officers know each other best and know very well who and how much is worth. The civil power must not be the weakest link in the Armed Forces. The same principle of semi-direction has to be respected when it comes to weapons, equipping, logistics, exercises and everything that makes the Armed Forces capable, elite and ready to meet its main task in all turbulent historical circumstances-to preserve the sovereignty of its state and the freedom of the people.

\section{Acknowledgment}

The paper was written as a part of the research on the scientific project of the Military Academy of the Defense University „The military in the political system of Serbia”, which is financed by the Ministry of Defense of the Republic of Serbia (project number VA-DH/1/19-21).

\section{Endnotes}

'Weber M.,Wirtschaft und Gesellschaft, Tubingen, 1956, p. 28 
${ }^{2}$ The most significant theoretical contribution to recent political sociology is Foucault's definition of power. His book can be used in the analysis of the impact of power in unexpected places and in an unexpected way. On this basis, it is possible to redefine politics as an opportunity to resist power and transform social practice outside the state.

${ }^{3}$,Economic power is the basis of political power and... closely related to it... and vice versa, political power serves to increase economic power. Together, they represent the social power with others" [1].

${ }^{4}$ Political power can be defined as: ,the ability of the social power holders to achieve their interests and goals through political activity-action independently of the will, interests and goals of other social and political entities" [22].

${ }^{5}$, He is inseparable from all great historical events of the society and in them he often played a significant, and sometimes crucial role..." [19]

${ }^{6}$,The officer is the only official to who the State...gave the general authority of its sovereign power, because it placed the citizens in its hands, and forced them to completely obey it..." [23]

${ }^{7}$,Effective civilian control of the military is the exception rather than the rule in the 2oth century. Only a limited number...of democracies in the economically strongest countries in Europe and North America has never experienced greater temptations of democratic control over the military..." [4]

${ }^{8}$,In the theories of the Western scientists, the relation between the military and the state can be divided into three concepts: liberal (civilian control over the military), conservative(independence and the influence of the military on the state policy), militaristic (the rule of the military groups in the state)..." [24]

9[26], quoted according to: M. Howard (ed.) Soldiers and Governments, Nine Studies in Civil-Military Relations, London, 1975 , pp. 11-12.

${ }^{10}$ There were two concepts of the role of the military: the idea of a smaller standing army (Washington and Hamilton) and the doctrine of unarmedness and isolation in relation to the world political conflicts (Jefferson and Madison), which were the enemies of the military because they saw it as a restorer of tyranny.

",The principle of the military subordination to official civilian authorities derives from: a) the democratic doctrine of the rule of law and b) the theory of war developed by Karl von Clausewitz, according to which war is only an instrument of politics (...the military power should be subordinated to civilian political decision-makers). The democratic aspects of civil-military relations have two main versions: a) parliamentary and b) presidential... the parliament, through the government composed of the parliamentary majority, controls the military and makes the political decisions regarding the military organization, promotion of personnel, and according to the other one, the president performs the function of Commander-in-Chief of the Armed Forces or... the Supreme Commander, the legislature controls budget. In both... types of democratic civilian control, there is the strict separation of competencies between political (civilian) and professional (military) hierarchies...” [4]

${ }^{12}$,The feature of coups d'état is that they take place in the countries that have mostly not built their political system, which are unstable and hierarchically organized because the armed forces generally cannot solve any problem in the country in the long run... The logic of the military is the logic of hierarchy, the main two principles are subordination and single seniority, and that cannot function in a community where social relations are much more complex, finer and more elastic. It happens that some of the soldiers think that they can solve things with a firm hand, quickly and efficiently according to the model of the barracks, but later it quickly turns out that what should be a solution is becoming an increasing problem. Power very easily becomes greedy, then everything is done to prolong it and that is why the putschists introduce soldiers into the civilian sectors, which is not good, because a soldier does not know how to face the community problems...Latin America and Africa have been synonymous with coups and showed it is possible that there may be some stabilization immediately and in the short run, but that in the long run these regimes end in dictatorship, tyranny and lead to the new decline of those countries." Ilija Kajtez, interview on Sputnjik: „Šta se desi kad se zapadni predatori ustreme na neku državu” April 14, 2019 (the interview was led by Nataša Milosavljević) [25].

${ }^{13}$ „One of the main problems that the military regimes face is the attitude towards the non-military process of conducting politics... The following problem that the military regimes face is the problem of separating political from purely military functions. After some time, the officers in political positions begin to perform the function of politicians, which again causes tensions between the military and political part of the government" [4].

\section{REFERENCES}

1. Barle Adolf. Power. New York: Harcourt, Brace \& World, Inc. 1969. [Google Scholar]

2. Bauman Zygmunt. Inequalitiy in liquid modern times [Internet]. [cited 4 mart 2021]. Available from: https://www.youtube.com/watch?v=ZTvouU2_2Ho.

3. Burke E. Speech on the Army Estimates (1790), Collected Works. 1883. [Google Scholar]

4. Dal Robert. Poliarhija. Beograd: Filip Višnjić. 1997. [Google Scholar] 
5. Eshil. Okovani Prometej. Beograd: Rad. 1960. [Google Scholar]

6. Filipović V, red. Filozofijski riječnik. Zagreb: Nakladni zavod Matice hrvatske. 1984. [Google Scholar]

7. Goodpaster J, Huntington SP. Civil-Military Relations. Washington: American Enterprise Institute. 1977. [Google Scholar]

8. Kajtez llija, Starčević Srđan, Ružičić Bojana. The essence of phenomenon of peace and the notion of peace building. Vojno delo. 2018;70(8):5-23. [SCIndeks] [PDF] [Google Scholar]

9. Oppenheim FE. Dimensions of freedom: An analysis. New York. 1961. [Google Scholar]

10. Petrović Gajo. Filozofija i revolucija. Zagreb: Naprijed. 1970. [Google Scholar]

11. Supek Rudi. Zanat sociologa. Zagreb: Školska knjiga. 1983. [Google Scholar]

12. Vjatr Ježi. Sociologija vojske. Beograd: VINC. 1987. [Google Scholar]

13. Vauhnik Vladimir. Nevidljivi front, predgovor. Beograd: Dobrotoljublje. 2019. [Google Scholar]

14. Gave Andre. Veština komandovanja. Beograd: VINC. 1993. [Google Scholar]

15. Galtung Johan. Mirnim sredstvima do mira - mir i sukob, razvoj i civilizacija. Beograd: Službeni glasnik + Jugoistok XXI. 2009. [Google Scholar]

16. Grupa autora. Amnezija javnosti - od propagande do terorizma. Beograd: Grafo-komerc. 2004. [Google Scholar]

17. Dos Fransoa. Istorija strukturalizma. Loznica: Karpos. 2019. [Google Scholar]

18. Đorđević Jovan. Politički sistem. Beograd: Savez udruženja pravnika Jugoslavije. 1967. [Google Scholar]

19. Enciklopedija političke kulture. Beograd: Savremena administracija. 1993.

20. Kajtez Ilija. Sociologija. Beograd: MC Odbrana. 2019. [Google Scholar]

21. Milosavljević Slavoljub. Politička akcija. Beograd: FPN-Institut za političke studije. 1977. [Google Scholar]

22. Pavlović Vukašin. Politička moć. Beograd: Zavod za udžbenike. 2012. [Google Scholar]

23. Simeunović Dragan. Teorija politike I deo. Beograd: Nauka i društvo. 2002. [Google Scholar]

24. Starčević Srđan. Revolucija i legitimnost. Beograd: Čigoja štampa. 2020. [Google Scholar]

25. Stojanović R. Sila i moć u međunarodnim odnosima. Beograd: Radnička štampa. 1982. [Google Scholar]

26. Todorić Slobodan. Civilno-vojni odnosi. Beograd: Vojnoizdavački zavod. 2004. [Google Scholar]

\title{
Filozofsko poimanje državne vlasti (društvene moći) i vojske (oružane sile)
}

\begin{abstract}
Sažetak:
Autor je u radu nastojao pojasniti zašto je za državnu vlast relevantan pojam društvene moći, a za vojsku je primerenije govoriti o oružanoj sili. lako je vrlo svestan isprepletenosti, uzajamnosti i bliskosti državne vlasti i organizacije vojske, kao i pojmova moći i sile, autor želi da naglasi njihove razlike. Nije moguće govoriti o vlasti bez pomoći i oslonca na oružanu silu, a neme te oružane sile koja ne baštini svoj smisao i zadatak i cilj u državnoj vlasti. Mogući su samo kratkotrajni periodi da se vojna sila osamostali, ali se odmah vraća u okrilje državne vlasti ili sama armija formira državnu vlast, jer joj treba izvor legitimiteta. Ono što je prvo i osnovno pravilo jeste da se nigde ne može govoriti o istinskoj vlasti ukoliko onaj koji je na vlasti ne kontroliše oružanu silu u svojoj zajednici, plemenu, rodu, klasi, politici, državi i društvu. Prosto nije moguće ni zamisliti, a kamoli da se to realno dešava, da onaj koji vlada jednom zajednicom ili društvom nije i vrhovni komandant oružanih snaga. Osnovna ideja jeste da se vidi koje su neprikosnovene sfere društva u kojima treba da dominira politika, a gde je najbolje polje delovanja oružanih snaga i kako i na koji način se regulišu njihovi odnosi koji su bliski, ali često i napeti.
\end{abstract}

Ključne reči: vlast; državna moć; vojska; vojna sila; lojalnost; civilno-vojni odnosi 